\title{
ライズの高い支持架構付き円筒ラチスシェルの地震応答評価 RESPONSE EVALUATION OF HIGH-RISE CYLINDRICAL LATTICE SHELL ROOFS WITH SUPPORTING SUBSTRUCTURES
}

\author{
竹内 徹*1, 渡辺 覚*2, 熊谷知彦*3, 小河利行*4 \\ Toru TAKEUCHI, Satoru WATANABE, Tomohiko KUMAGAI \\ and Toshiyuki OGAWA
}

\begin{abstract}
Seismic response of cylindrical lattice shell roofs are known to be affected by its rise and supporting substructures. The authors have proposed simple method for estimating response of such shell roofs using amplification factors, however, that does not cover high-rise shell roofs.In this paper, simple response evaluation method for lattice shell roofs with high-rise proportions supported by various stiffness of substructures is proposed using continuous approach as the previous studies including those for high-rise domes, and their validities are discussed against response spectrum analyses based on CQC method.
\end{abstract}

Keywords : Cylindrical Lattice Shell, Seismic Response Evaluation, High-rise, Response Spectrum Analysis, CQC method 円筒ラチスシェル，地震応答評価，高ライズ，応答スペクトル法，CQC 法

\section{1. 序}

屋根型円筒ラチスシェルは学校体育館をはじめ展示場やスポーツ 施設など多くの中規模空間構造に使用されており, 災害時には避難 所として利用される等, 内装材も含めた耐震性能の確保が重要な課 題となる。これらの屋根架構はライズを有するため水平地震動に対 しても鉛直振動が励起されるため, その地震応答を既往の重層構造 物を対象とした設計用水平荷重に従って評価することは妥当ではな い。円筒ラチスシェルおよびアーチ構造物では梁間方向の水平地震 入力に対し，鉛直振動を伴う多くの振動モードが現れ，さらにそれ らが支持架構の動的特性によりさまざまに励起されるため，単純な 重層モデルの設計用せん断力を水平に加えるだけではその応答を表 現することができない。

これらの課題に対し，過去に行われた多くの研究 1)-15)では山田聖 志らを中心に静的地震荷重の設定や時刻歴応答解析結果を簡便に予 測する様々な手法が提案されているが，その多くは低ライズの屋根 を対象としている。高ライズの屋根を対象とした研究として, 加藤, 向山ら ${ }^{10), 11}$ は半開角 $60^{\circ} \sim 120^{\circ}$ の高ライズ単層ラチスドームについ て固有值解析および時刻歴応答解析による分析から等価な静的地震 力についての提案を行っている。また, 筆者ら ${ }^{15)}$ は半開角 $30^{\circ} \sim 90^{\circ}$ の異なる網目形状, 支持架構を有するラチスドームに対し, 固有值 解析や応答スペクトル法による分析，単純アーチモデルの応答理論 解を参照して低ライズドームから高ライズドームまで連続的に定義 された静的荷重の設定法を提案している。このように高ライズドー
ムを対象とした静的地震荷重の設定法についての研究は行われてい るが, 高ライズ円筒ラチスシェルを対象としたものは見当たらない。 筆者ら ${ }^{12)-14}$ は下部構造で支持された円筒ラチスシェルおよびドー ムについて，屋根部の面外剛性がある程度以上確保されれば卓越モ 一ドが数種類に集約されることを明らかにし，下部支持構造との剛 性比および質量比の関係を用いて屋根各部の応答加速度をある程度 の精度で簡便な式で表現することが可能であることを示した。ただ し, 対象とした円筒ラチスシェルは半開角が $20^{\circ} \sim 40^{\circ}$ (ライズ/スパン 比 0.18 0.36)に限られており, これ以上高ライズの円筒シェルにつ いての適用性は確認されていない。

そこで本研究では竹内, 小河ら ${ }^{13), 14)}$ による低ライズドームおよび 円筒シェルに関する研究および竹内, 熊谷ら ${ }^{15}$ による高ライズドー ムに関する研究を応用し，支持架構付き高ライズ円筒ラチスシェル およびアーチ構造の梁間方向の地震入力に対する応答を弾性範囲に おいて評価する手法を誘導すると共に，その精度を確認することを 目的とする。まず半開角 $30^{\circ} \sim 90^{\circ}$ の筒シェルおよびアーチの屋根 モデルの振動モードを固有值解析や応答スペクトル法により分析し, 2 質点アーチモデルの応答理論解を参照して応答増幅率の設定を行 う。この際，屋根面の加速度分布関数の表現に極座標を導入する。 続いて下部構造の剛性を変化させることによる屋根構造の卓越モ一 ドおよび最大応答の変化を調查する。以上により下部構造による増 幅効果を考慮し，低ライズから連続的に定義された高ライズの静的 荷重の設定を試みる。

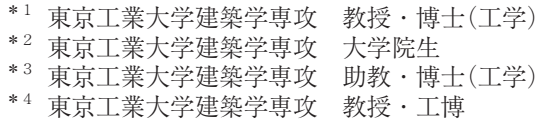

Prof., Dept. of Arch. And Building Eng., Tokyo Institute of Technology, Dr. Eng. Graduate Student, Dept. of Arch. And Building Eng., Tokyo Institute of Technology Assist. Prof., Dept. of Arch. And Building Eng., Tokyo Institute of Technology, Dr. Eng. Prof., Dept. of Arch. And Building Eng., Tokyo Institute of Technology, Dr. Eng. 


\section{2. 検討モデル}

検討モデルは図 1 に示すような学校体育館規模の屋根型円筒シェ ルおよび円筒アーチである。節点 $\mathrm{A}, \mathrm{O}, \mathrm{A}$ をを通る円弧を中央線と呼 ぶ。屋根架構の半開角 $\theta$ は $30^{\circ} \sim 90^{\circ}$ まで $10^{\circ}$ 刻みの 7 種とする。構成 部材は全て円形鋼管とし, 固定荷重は屋根荷重 $1.18 \mathrm{kN} / \mathrm{m}^{2}$, 壁荷重 で $0.98 \mathrm{kN} / \mathrm{m}^{2}$ とする。屋根架構は固定荷重の夕を受ける時の部材応 力がほぼ一様になるよう設計する。支持架構は, ベースシアー係数 $C_{0}=0.3\left(Z, R_{t}, \mathrm{~A}_{\mathrm{i}}=1.0\right)$ のせん断力, および屋根架構の固定荷重相当の 軸力に対して弾性範囲とし, 層間変形角が $1 / 200$ 以下となるよう設 計する。各モデル間でラチス材の部材長の差を小さくするため, 部 材長が $400 \mathrm{~mm}$ 以下となるよう開角方向分割数を決定する。表 1 に 形状諸元, 表 2 に部材諸元, 表 3 に屋根架構の節点数および部材数 を示す。屋根架構だけで構成されるシェル，アーチ屋根モデル(RS, RA) と支持架構を有するモデルを用いる。後者には, 上記のように 決定した非剛床モデル $(\mathrm{FS}, \mathrm{FA})$ と, 支持架構の妻面梁, 桁行梁を剛梁 に置換し水平ブレースを設け, 支持架構の梁の変形による屋根架構 の地震応答への影響を無くした剛床モデル(FSf, FAf)を設定する。

$\mathrm{RS}$ モデルでは四隅の支持点をピン支持, それ以外の周辺節点は辺 直行方向ローラー支持とし, RA モデルでは桁行方向の節点をピン 支持，妻面節点は自由としている。支持架構付きモデルでは，柱脚 を固定支持，屋根架構と支持架構の間はピン接合とする。それぞれ 弾性範囲で設計した柱を基準に曲げ剛性を $0.01,0.1 ， 1 ， 10,100$ 倍の 5 通りに設定寸ることで支持架構の固有周期を変化させる。

\section{3. 屋根モデルの応答特性}

固定荷重による幾何非線形性を考慮した固有值解析を行う。RS30, 60,90, RA30, 60, 90 の卓越固有モードを，有効質量比および固有周

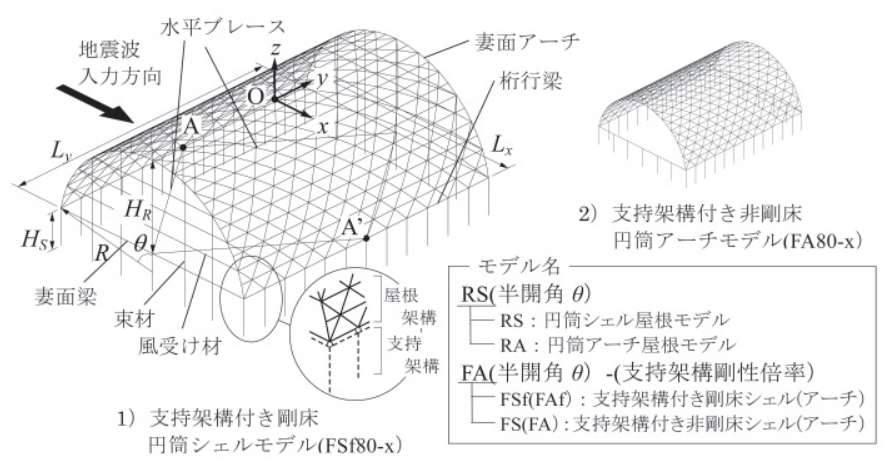

図 1 解析モデル

表 1 形状諸元

表 3 屋根架構節点数および部材数

\begin{tabular}{|c|c|c|c|c|c|c|}
\hline 半開苗 $\left.\theta 0^{\circ}\right)$ & \begin{tabular}{|l|l|l|l|l|l|l|}
30 & 40 & 50 & 60 & 70 & 80 & 90 \\
\end{tabular} & \multicolumn{2}{|c|}{ 半開角 $\theta\left(^{\circ}\right)$} & 30,40 & \begin{tabular}{l|l|}
50 & 60,70 \\
\end{tabular} & 80,90 \\
\hline 梁間スパン $L_{x}(\mathrm{~m})$ & 36.0 & \multirow[b]{2}{*}{ 即泉 } & RS & 185 & \begin{tabular}{l|l}
245 & 255 \\
\end{tabular} & 373 \\
\hline 桁行スパン $L_{r}(\mathrm{~m})$ & $\frac{36.0}{48.0}$ & & RA & 175 & 229 & 337 \\
\hline 曲率半徍 $R(\mathrm{~m})$ & \begin{tabular}{|l|l|l|l|l|l|l|l|}
36.0 & 28.0 & 23.5 & 20.8 & 19.2 & 18.3 & 18.0 \\
\end{tabular} & \multirow{2}{*}{ 部材数 } & RS & 496 & \begin{tabular}{l|l|}
664 & 686 \\
\end{tabular} & 1016 \\
\hline ライズ $H_{R}(\mathrm{~m})$ & \begin{tabular}{|l|l|l|l|l|l|l|}
4.82 & 6.55 & 8.39 & 10.4 & 12.6 & 15.1 & 18.0 \\
\end{tabular} & & RA & 474 & 628 & 936 \\
\hline 支持柱長さ $H_{S}(\mathrm{~m})$ & 6.0 & \multicolumn{2}{|c|}{ 開角方向分割数 } & 6 & 8 & 12 \\
\hline
\end{tabular}

表 2 部材諸元

\begin{tabular}{|c|c|c|c|c|c|c|}
\hline \multicolumn{2}{|r|}{ 半開角 $\theta\left({ }^{\circ}\right)$} & $\begin{array}{c}\text { 外径 } \\
D(\mathrm{~mm})\end{array}$ & $\begin{array}{l}\text { 厚さ } \\
t(\mathrm{~mm})\end{array}$ & $\begin{array}{l}\text { 断面積 } \\
A\left(\mathrm{~mm}^{2}\right)\end{array}$ & \begin{tabular}{|c|} 
䉼面二次 \\
モーメント \\
$I\left(\times 10^{4} \mathrm{~mm}^{4}\right)$ \\
\end{tabular} & $\begin{array}{l}\text { ヤング係数 } \\
E\left(\mathrm{~N} / \mathrm{mm}^{2}\right)\end{array}$ \\
\hline \multicolumn{2}{|c|}{ ラチス材 } & 165.2 & $\begin{array}{l}4.0 \\
6.0 \\
8.0\end{array}$ & $\begin{array}{l}2027 \\
3001 \\
3951 \\
\end{array}$ & $\begin{array}{c}658 \\
952 \\
1224 \\
\end{array}$ & \multirow{6}{*}{205000} \\
\hline \multirow{2}{*}{\multicolumn{2}{|c|}{$\frac{\text { 妻面アーチ }}{\text { 妻面梁 }}$}} & 558.8 & 19 & 32200 & 117500 & \\
\hline & & 355.6 & 11 & 11900 & 17695 & \\
\hline \multicolumn{2}{|c|}{ 桁行梁 } & 1016 & 3.0 & 92900 & 1130352 & \\
\hline \multirow{2}{*}{$\begin{array}{c}\text { 束材 } \\
\text { 風受け材 }\end{array}$} & $30-70$ & \multirow{2}{*}{318.5} & 6.0 & 5890 & 719 & \\
\hline & 80,90 & & 7.9 & 7709 & 930 & \\
\hline
\end{tabular}

期と併せて図 2 に示す。半開角の増加に伴い, 円筒シェル RS モデ ル，円筒アーチ RA モデルともに逆対称 1 波モード $(\mathrm{O} 1)$ の有効質量 比が増加する。図 3 に RS, RA モデルの逆対称 1 波モード固有周期 を示す。半開角 $\theta$ が $30^{\circ} \sim 60^{\circ}$ ま゙の範囲では RS モデルと RA モデル は同程度の固有周期となるが, $\theta=60^{\circ}$ 以上の範囲では半開角の増加に 伴って RA モデルの固有周期が増加しているのに対し, RS デルでは あまり増加しない。以上より高ライズの範囲では円筒シェルと円筒 アーチは異なった振動特性を持つことがわかる。

次に, 地震応答解析を行い, 地震応答特性にモデル形状・半開角 が与える影響を分析する。解析方法は，モード間の相関を考慮する CQC 法を用いた応答スペクトル法とする。本研究では CQC 法で採 用すべき振動モードの有効質量比和を既論文 ${ }^{14)}$ を参考に $98 \%$ 以上と

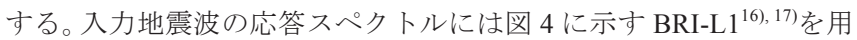
いる。

図 5 に CQC 法より得られる水平 ・ 鉛直応答加速度増幅率と $\theta$ と の関係を既論文 ${ }^{12)}$ で提案されている次式の応答増幅率 $F_{H, V}$ と併せて 示す。
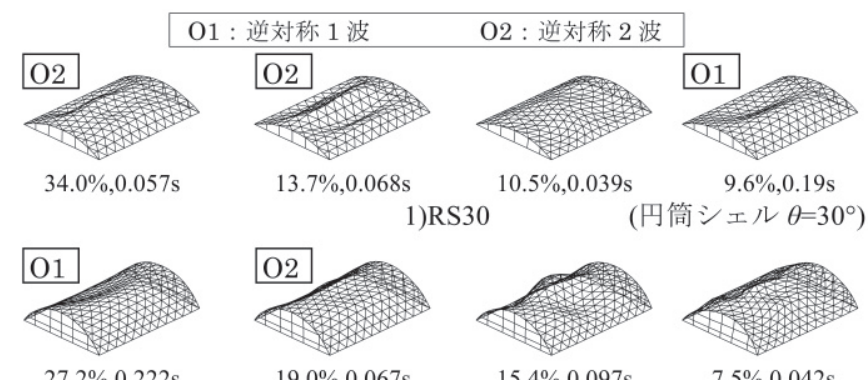

$27.2 \%, 0.222 \mathrm{~s}$

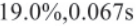

2)RS60

$7.5 \%, 0.042 \mathrm{~s}$
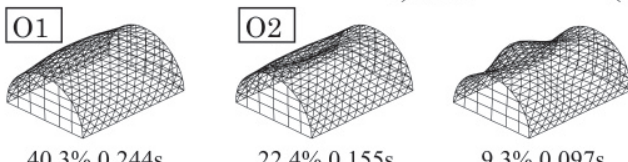

(円筒シェル $\theta=60^{\circ}$ )

$40.3 \%, 0.244 \mathrm{~s}$

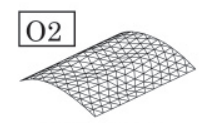

$39.3 \%, 0.061 \mathrm{~s}$

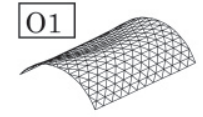

$41.6 \%, 0.245 \mathrm{~s}$

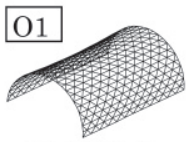

$76.4 \%, 0.369 \mathrm{~s}$ 有効質量比 固有周期

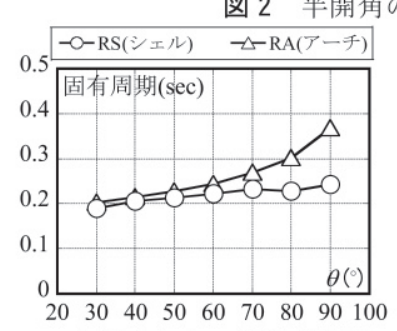

図 301 モード固有周期

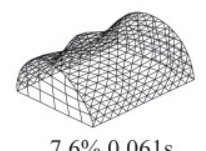

(円筒シェル $\theta=90^{\circ}$ )
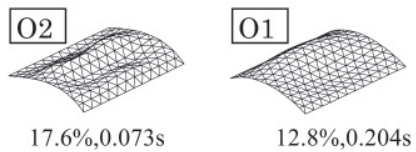

$12.8 \%, 0.204 \mathrm{~s}$

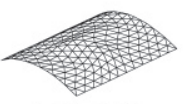

4)RA30

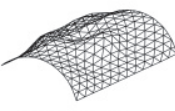

$13.0 \%, 0.069 \mathrm{~s}$

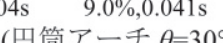
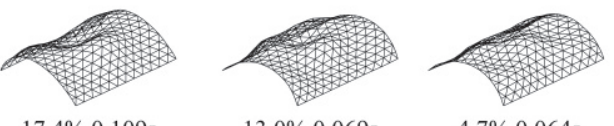

$4.7 \%, 0.064 \mathrm{~s}$ 5)RA60
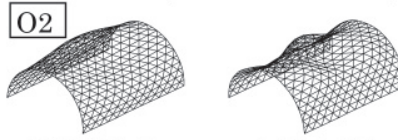

$2.8 \%, 0.086 \mathrm{~s}$ 6)RA90 の変化と卓越モード

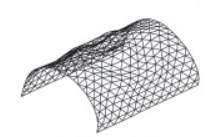

$1.4 \%, 0.039 \mathrm{~s}$ 円筒アーチ $\theta=90^{\circ}$ )

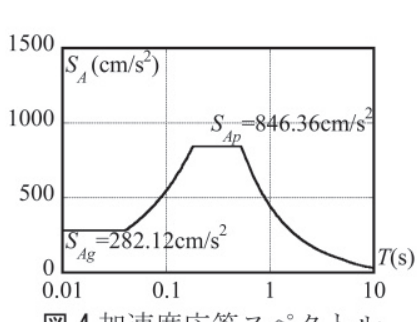




$$
\begin{gathered}
F_{H}= \begin{cases}3 / 2 & \left(0<R_{T} \leq 1 / 4\right) \\
1 / 2\left(\sqrt{1 / R_{T}}+1\right) & \left(1 / 4<R_{T} \leq 1\right) \\
1 & \left(1<R_{T}\right)\end{cases} \\
F_{V}= \begin{cases}3 C_{v} \theta & \left(0<R_{T} \leq 5 / 16\right) \\
\left(\sqrt{5 / R_{T}}-1\right) C_{v} \theta & \left(5 / 16<R_{T} \leq 5\right) \\
0 & \left(5<R_{T}\right)\end{cases}
\end{gathered}
$$

ただし， $C_{v}=1.33$ である。周期比 $R_{T}=T_{e q} / T_{R}, T_{e q}$ は屋根部を質点に置 換した 1 質点系での等価固有周期, $T_{R}$ は屋根モデル逆対称 1 波モー ドの固有周期である。

式(1),(2)において支持架構の無い屋根モデルでは $R_{T}$ は 0 であり, $F_{H}$ は $3 / 2$ で一定, $F_{V}$ は $3 C_{v} \theta$ で $\theta$ と比例関係となる。しかし図 5 を 見ると, CQC 解析值は半開角 $40^{\circ}$ 以上では式(1),(2)より外れ, 水平 応答増幅率 $F_{H}$ は一定値を超えて増大し, 円筒アーチ RA の鉛直応答 増幅率 $F_{V}$ は半開角 $60^{\circ}$ 以上の範囲において半開角の増加に伴い減少 する。これらの傾向は既論文 ${ }^{15)}$ の高ライズドームにおいても確認さ れている。一方, 円筒シェル RS の鉛直応答増幅率 $F_{V}$ はドームとは 異なり半開角の増加に伴い増加する傾向を示す。そこで既論文 ${ }^{14), 15)}$ を参照し，簡易アーチモデルを用いて応答増幅率を誘導することを 試みる。

円筒シェルおよび円筒アーチを図 6 に示すような 2 質点の線形モ デルに置換して水平応答増幅率および鉛直応答増幅率を誘導する。 各部材の軸変形は無いものとし, 各節点で回転バネを有するものと すると, 既論文 ${ }^{14)}$ より水平・鉛直応答増幅率として次式が得られる。

$$
\begin{aligned}
\frac{\left(\boldsymbol{a}_{R}\right)_{x}}{S_{A g}} & =\sqrt{\left(3 \beta_{R 1} u \sin \frac{3}{4} \theta\right)^{2}+\left(\boldsymbol{I}_{x} \cdot \frac{M_{R 2}}{M_{R}}\right)^{2}} \\
& =\sqrt{10 \sin ^{4} \frac{3}{4} \theta-2 \sin ^{2} \frac{3}{4} \theta+1} \\
\frac{\left(\boldsymbol{a}_{R}\right)_{y}}{S_{A g}} & =\sqrt{\left(3 \beta_{R 1} u \sin \frac{3}{4} \theta\right)^{2}+0}=3 \sin \frac{3}{4} \theta \cdot \cos \frac{3}{4} \theta
\end{aligned}
$$

ここに, $\boldsymbol{a}_{R}$ は屋根部の応答加速度ベクトル, $S_{A g}$ は最大入力加速度, $u$ は逆対称 1 波モードの固有ベクトルの要素, $\beta_{R 1}$ は水平入力に対す る曲げ変形モードの刺激係数, $M_{R}$ は全有効質量, $M_{R 1}$ は曲げ変形モ ードの有効質量, $M_{R 2}$ は $M_{R 1}$ を除いた残りの有効質量であり, $M_{R 2}=M_{R}-M_{R 1}$ である。

式(3),(4)を参考にして応答増幅率近似式を以下のように設定する。 水平方向：

$\frac{\left(\boldsymbol{a}_{R}\right)_{x}}{S_{A g}} \approx C_{H(\theta)}=C_{1} \sin ^{2} 3 \theta / 4-C_{2} \sin 3 \theta / 4+C_{3}$

鉛直方向(円筒アーチ) :

$$
\frac{\left(\boldsymbol{a}_{R}\right)_{y}}{S_{A g}} \approx C_{V(\theta)}=C_{4} \sin 3 \theta / 4 \cdot \cos 3 \theta / 4
$$

ここで, $C_{1}=4.00, C_{2}=1.33, C_{3}=1.50, C_{4}=6.00$ である。

図 5 中に式(5), (6)の值を加えて示寸。水平応答増幅率 $F_{H}$ は式(5) により円筒シェル，円筒アーチともにその傾向を表現できている。 また, 鉛直応答増幅率 $F_{V}$ は式(6)により円筒アーチの傾向を捉えら れているが, 円筒シェルでは高ライズ領域で増加する傾向を表現で きていない。そこで円筒シェルにおける鉛直応答増幅率を高ライズ 領域で補正することを試みる。円筒シェルの $F_{V}$ が高ライズの範囲で

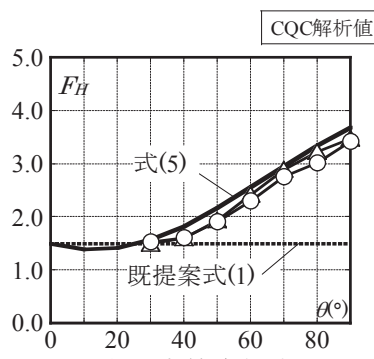

1)水平応答増幅率

図 5 半開角に伴う応答増幅率の変化

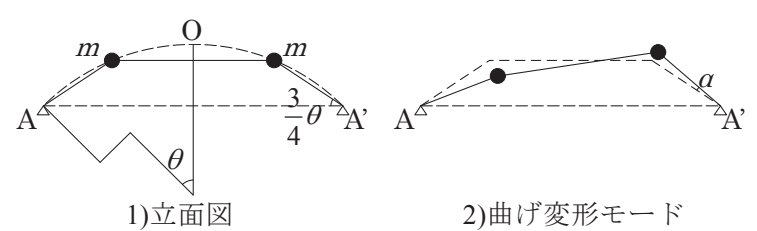

図 62 質点アーチモデル

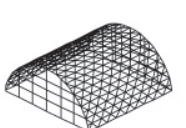

a) $L_{y} / L_{x}=1.0$

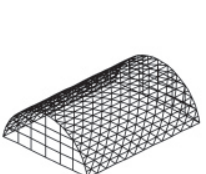

b) $L_{y} / L_{x}=1.3$

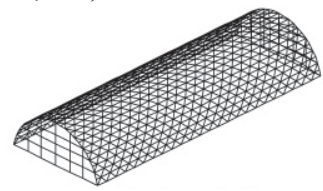

c) $L_{y} / L_{x}=2.7$
図 7 桁行/スパン比の異なるモデル

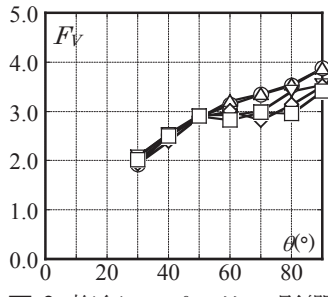

図 8 桁行/スパン比の影響

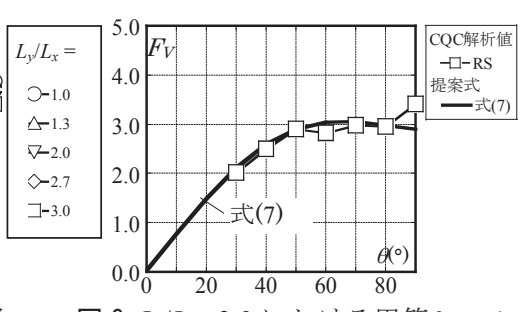

図 $9 L_{y} / L_{x}=3.0$ における円筒シェル の鉛直応答増幅率
も増加傾向を示すのは妻面の拘束によるものと考え, 梁間方向長さ $L_{x}$ に対する桁行方向長さ $L_{y}$ の比である栴行/スパン比 $L_{y} / L_{x}$ を図 7 の ように変化させる。各桁行/スパン比での最大応答増幅率を図 8 に示 す。同図よりその上昇率はスパンに対し桁行長が長くなると小さく なることがわかる。以上より式(6)に, 図 8 に示寸桁行/スパン比 $\left(L_{y} / L_{x}\right)$ の影響を考慮して円筒シェルの鉛直応答増幅率 $F_{V}$ を下式のように 設定する。

鉛直方向(円筒シェル) :

$$
\begin{aligned}
& \frac{\left(\boldsymbol{a}_{R}\right)_{y}}{S_{A g}} \approx C_{V(\theta)}=C_{4} \sin 3 \theta / 4 \cdot \cos 3 \theta / 4+C_{5}(\theta-1 / 2)^{4}\left(L_{x} / L_{y}\right) \\
& \text { ここで } C_{5}=0.60, L_{x} / L_{y}<1 \text { とする。 }
\end{aligned}
$$

図 5 中に式(7)の值を加えて示す。式(7)により高ライズの領域でも 増加する傾向を捕捉できている。ここで円筒シェルを桁行方向へ伸 長し,$L_{y} / L_{x}=3.0$ とした時の鉛直応答増幅率の比較を図 9 に示す。

このように桁行/スパン比 $L_{y} / L_{x}$ が大きくなるにつれてライズの影 響はアーチに近づく。式(5) (7)は $\theta$ が 0 に近づくにつれ既定案式 (1),(2)とほぼ一致するようになっている。そこで式(5) (7)を用いて支 持架構付きの式(1),(2)を次式に置き換える。式(8), (9)は $\theta$ が $40^{\circ}$ 以下 の範囲では式(1), (2) とほぼ同等の值となる。

$$
F_{H}= \begin{cases}C_{H(\theta)} & \left(0<R_{T} \leq 1 /\left(2 C_{H(\theta)}-1\right)^{2}\right) \\ 1 / 2\left(\sqrt{1 / R_{T}}+1\right) & \left(1 /\left(2 C_{H(\theta)}-1\right)^{2}<R_{T} \leq 1\right) \\ 1 & \left(1<R_{T}\right)\end{cases}
$$




$$
F_{V}= \begin{cases}3 C_{V(\theta)} & \left(0<R_{T} \leq 5 / 16\right) \\ \left(\sqrt{5 / R_{T}}-1\right) C_{V(\theta)} & \left(5 / 16<R_{T} \leq 5\right) \\ 0 & \left(5<R_{T}\right)\end{cases}
$$

式(8),(9)より屋根部各方向の最大加速度応答值が得られるので, 次に中央線 $\mathrm{AOA}^{\prime}$ 上の応答加速度分布について分析する。図 10 に中 央線上応答加速度を示す。水平方向では半開角の増加に伴い応答加 速度は増大し, その分布形状も外周部でより大きな形状へと変化し ている。既論文 ${ }^{15}$ における高ライズドームにおいても同様の傾向が 見られる。既論文 ${ }^{15)}$ では既往の評価式が屋根部の水平投影座標に対 し定義されていることに起因するとして, 以下の手順によって評価 式を補正している。まず極座標を屋根部節点に導入し, 既往の加速 度分布評価式における応答加速度の作用方向を水平から面内一，鉛 直から面外一と読み替える。次に面内 ・面外方向加速度を水平・鉛 直方向に分解し再合成することで加速度分布を得る。本研究におい ても同様の手法を用いて半開角の変化に対応した加速度分布評価式 を導出する。既論文 ${ }^{14}$ における加速度応答分布式は下式である。

円筒シェル：

$$
\begin{aligned}
& A_{H}(x, y)=A_{e q}\left\{1+\left(F_{H}-1\right) \cos \pi\left(\frac{x}{L_{x}}\right) \cos \pi\left(\frac{y}{L_{y}}\right)\right\} \\
& A_{V}(x, y)=A_{e q} F_{V} \sin \pi\left(\frac{2 x}{L_{x}}\right) \cos \pi\left(\frac{y}{L_{y}}\right)
\end{aligned}
$$

円筒アーチ：

$$
\begin{aligned}
& A_{H}(x, y)=A_{e q}\left\{1+\left(F_{H}-1\right) \cos \pi\left(\frac{x}{L_{x}}\right)\right\} \\
& A_{V}(x, y)=A_{e q} F_{V} \sin \pi\left(\frac{2 x}{L_{x}}\right)
\end{aligned}
$$

式(10) (13)を図 11 に示寸極座標を用い, 面内・面外方向の加速度 と考え表現すると式(14) (17)のようになる。

円筒シェル：

$$
\begin{aligned}
& A_{H(x, y)} \rightarrow A_{\text {ino }(\varphi, y)}+A_{\text {inl }(\varphi, y)}=A_{e q}+\left\{A_{e q}\left(F_{H}-1\right) \cos \left(\frac{\pi \varphi}{2 \theta}\right) \cos \pi\left(\frac{y}{L_{y}}\right)\right\} \\
& A_{V(x, y)} \rightarrow A_{\text {out }(\varphi, y)}=A_{e q} F_{V} \sin \left(\frac{\pi \varphi}{\theta}\right) \cos \pi\left(\frac{y}{L_{y}}\right)
\end{aligned}
$$

円筒アーチ：

$$
\begin{aligned}
& A_{H(x, y)} \rightarrow A_{\text {ino }(\varphi, y)}+A_{i n 1(\varphi, y)}=A_{e q}+\left\{A_{e q}\left(F_{H}-1\right) \cos \left(\frac{\pi \varphi}{2 \theta}\right)\right\} \\
& A_{V(x, y)} \rightarrow A_{\text {out }(\varphi, y)}=A_{e q} F_{V} \sin \left(\frac{\pi \varphi}{\theta}\right)
\end{aligned}
$$

ここで, 図 12 に示すように, $A_{\text {in } 0(\varphi, y)}$ は水平入力加速度 $A_{e q}$ であり, $A_{\text {in } 1(\varphi, y)}, A_{\text {out }(\varphi, y)}$ はそれぞれシェルの振動によって生じる面内方向の加 速度の増幅成分，および面外方向の加速度である。

さらに各加速度の作用方向を考慮し, 面内加速度成分 $A_{\text {in } 1(\varphi, y)}$ お び面外加速度 $A_{\text {out }(\varphi, y)}$ を水平・鉛直方向に座標変換し, その水平成分, 鉛直成分をそれぞれ $A_{H(\varphi, y)}, A_{V(\varphi, y)}$ に加えると下式のようになる。

円筒シェル：

$$
\begin{aligned}
A_{H(\varphi, y)}=A_{\text {ino }(\varphi, y)}+A_{\text {inl }(\varphi, y)} \cdot \cos \alpha_{H} \varphi+A_{\text {out }(\varphi, y)} \cdot \sin \alpha_{V} \varphi \\
=A_{e q}\left\{1+\left(F_{H}-1\right) \cos \left(\frac{\pi \varphi}{2 \theta}\right) \cos \pi\left(\frac{y}{L_{y}}\right) \cdot \cos \alpha_{H} \varphi\right. \\
\left.+F_{V} \sin \left(\frac{\pi \varphi}{\theta}\right) \cos \pi\left(\frac{y}{L_{y}}\right) \cdot \sin \alpha_{V} \varphi\right\}
\end{aligned}
$$
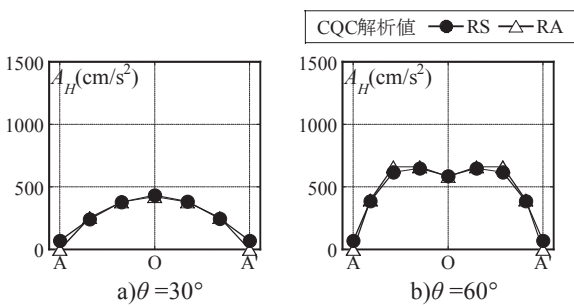

1) 水平方向
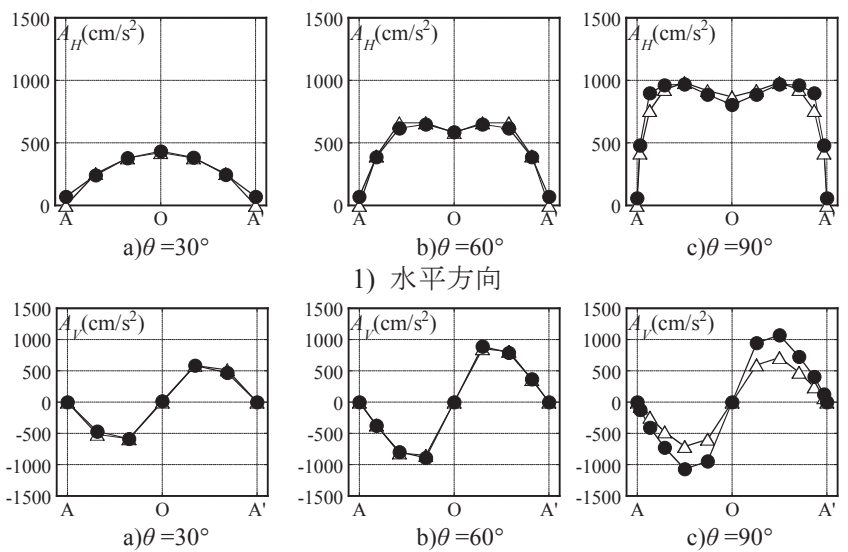

c) $\theta=90^{\circ}$

2) 鉛直方向

図 10 中央線上の応答加速度

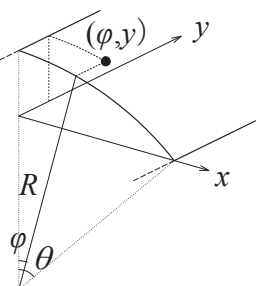

図 11 屋根部の極座標表示

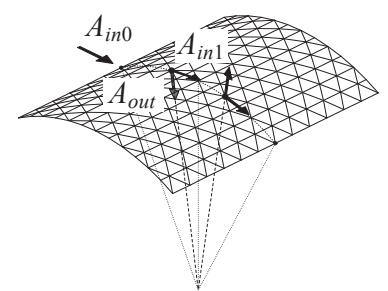

図 12 屋根部加速度分布

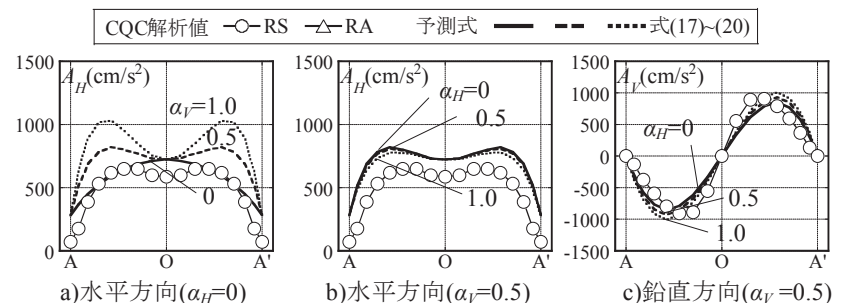

1) 円筒シェル RS モデル
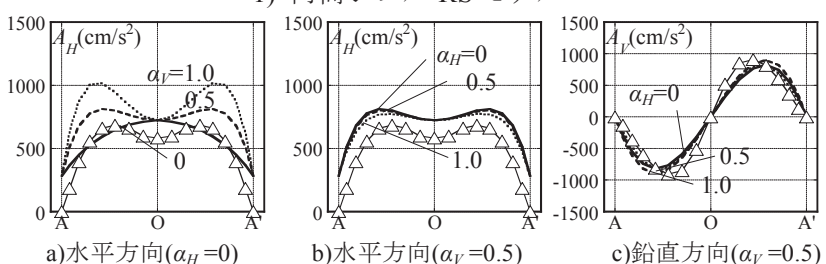

b)水平方向 $\left(\alpha_{V}=0.5\right)$

c)鉛直方向 $\left(\alpha_{V}=0.5\right)$

2) 円筒アーチ RA モデル

図 $13 \alpha_{H}, \alpha_{V}$ の変化に伴う応答加速度分布 $\left(\theta=60^{\circ}\right)$

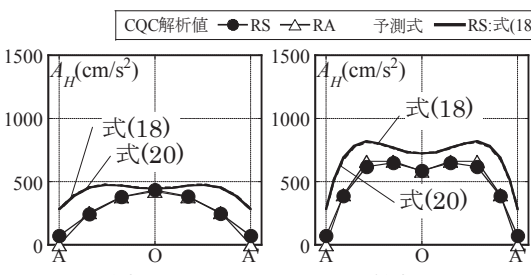

a) $\theta=30^{\circ}$

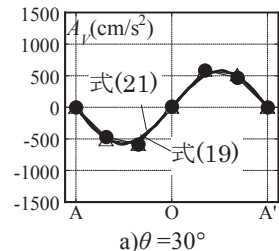

1) 水平方向

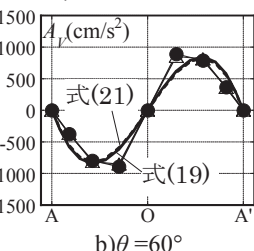

2) 鉛直方向

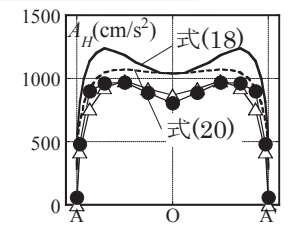

c) $\theta=90^{\circ}$

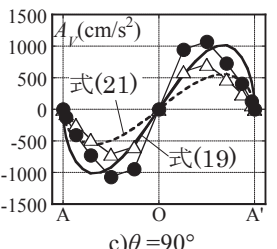

c) $\theta=90^{\circ}$
図 14 屋根モデルにおける提案評価法の応答加速度の精度 


$$
\begin{aligned}
A_{V(\varphi, y)}= & A_{\text {out }(\varphi, y)} \cdot \cos \alpha_{V} \varphi+A_{\text {inl }(\varphi, y)} \cdot \sin \alpha_{H} \varphi \\
= & A_{\text {eq }}\left\{F_{V} \sin \left(\frac{\pi \varphi}{\theta}\right) \cos \pi\left(\frac{y}{L_{y}}\right) \cdot \cos \alpha_{V} \varphi\right. \\
& \left.+\left(F_{H}-1\right) \cos \left(\frac{\pi \varphi}{2 \theta}\right) \cos \pi\left(\frac{y}{L_{y}}\right) \cdot \sin \alpha_{H} \varphi\right\}
\end{aligned}
$$

円筒アーチ：

$$
\begin{aligned}
A_{H(\varphi, y)} & =A_{\text {ino }(\varphi, y)}+A_{\text {in } 1(\varphi, y)} \cdot \cos \alpha_{H} \varphi+A_{\text {out }(\varphi, y)} \cdot \sin \alpha_{V} \varphi \\
& =A_{\text {eq }}\left\{1+\left(F_{H}-1\right) \cos \left(\frac{\pi \varphi}{2 \theta}\right) \cdot \cos \alpha_{H} \varphi+F_{V} \sin \left(\frac{\pi \varphi}{\theta}\right) \cdot \sin \alpha_{V} \varphi\right\} \\
A_{V(\varphi, y)} & =A_{\text {out }(\varphi, y)} \cdot \cos \alpha_{V} \varphi+A_{\text {in }(\varphi, y)} \cdot \sin \alpha_{H} \varphi \\
& =A_{\text {eq }}\left\{F_{V} \sin \left(\frac{\pi \varphi}{\theta}\right) \cdot \cos \alpha_{V} \varphi+\left(F_{H}-1\right) \cos \left(\frac{\pi \varphi}{2 \theta}\right) \cdot \sin \alpha_{H} \varphi\right\}
\end{aligned}
$$

$\theta$ が小さくなるにつれ, 式(18) (21)は水平面投影式(10) (13)とほ ぼ同等となる。なお, 高ライズドームと同様に, 再合成に用いる傾 斜角に $\varphi$ そのものを用いると評価が過大となることが CQC 法によ る結果との比較よりわかっている。図 13 に示寸ように式(18) (21) 中の $\alpha_{H, V}$ を $0 \sim 1.0$ の範囲で変化させ比較した結果から既論文 ${ }^{15)}$ と同 様に式中の $\alpha_{V}=0.5, \alpha_{H}=0$ とし, 屋根部の加速度分布を評価する。

図 14 に式(18) (21)より得られる RS30, 60, 90, RA30, 60 ,90 の中央 線上応答加速度分布の精度を示す。式(18), (20)において $F_{V}$ の成分を 導入することで, 半開角の増加に伴う水平応答加速度の外周部の分 布形状の変化についても概ね表現できている。全ケースを通じ, $\theta=30^{\circ}$ の水平応答加速度において外周部を過大評価している他は, 概 放よい対応を示している。

図 15 に式(18) (21)を用いて評価した屋根各部の応答加速度に, 屋 根単位荷重を乗じて静的地震荷重として使用した際の評価法の精度 を示す。水平・鉛直変位および軸力について, 提案評価法は半開角 90に至るまで良好な対応を示す。曲げモーメントの精度は必ずしも

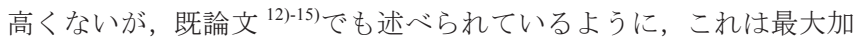
速度の包絡による静的荷重が高次モードによる部材応力を捕捉でき ないためであり, 屋根面内の最大曲げモーメントを全部材の断面検 定に使用寸るなどの対処が必要となる。

\section{4. 周期比の異なる支持架構付きモデルの応答特性}

本章では 3 章で検討した屋根モデルに支持架構を付加し, 支持架 構の周期を変化させることで周期比 $R_{T}$ の地震応答特性に与える影 響を分析する。

まず，支持架構の梁の変形による屋根架構の地震応答への影響を 無くした剛床モデルについて検討する。図 16 に FSf30, 60 ,90, FAf30, 60, 90 の下部構造剛性 $0.01,1,10,100$ 倍のモデルの卓越固有モード を有効質量比, 固有周期と併せて示す。既論文 ${ }^{15)}$ と同様に下部構造 剛性が 1 倍から 100 倍と大きくなるにつれ卓越固有モードの有効質 量比は低下寸るとともに, 有効質量比和 $98 \%$ に必要なモード数は増 加し, 高次の固有モードの有効質量比が増加する。また低ライズの 30 では逆対称 2 波モード $(\mathrm{O} 2)$ が卓越するが, 高ライズになるにつれ 逆対称 1 波モード $(\mathrm{O} 1)$ が卓越し, 下部構造剛性増加に伴う有効質量 比の低下率は下がる傾向を示す。下部構造剛性 0.01 倍では半開角に 依らず下部構造がスウェイするモードのみで $100 \%$ に近い有効質量 比和を持つ。また円筒シェルと円筒アーチはライズと下部構造剛性 の高い範囲で異なる固有周期，有効質量比を示す。

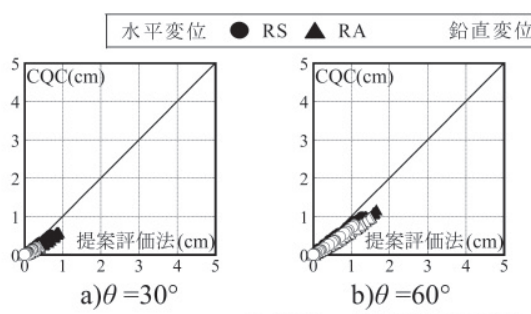

1)水平 ・ 鉛直応答変位

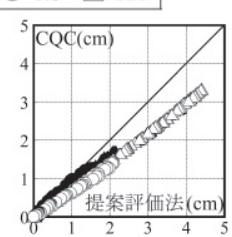

c) $\theta=90^{\circ}$
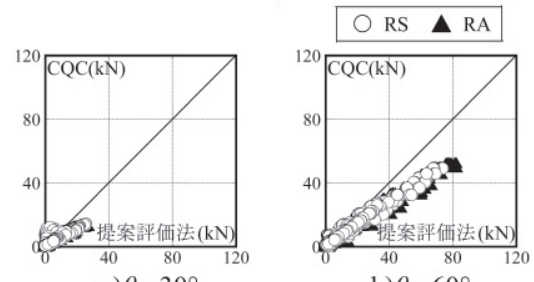

b) $\theta=60^{\circ}$

2)軸力

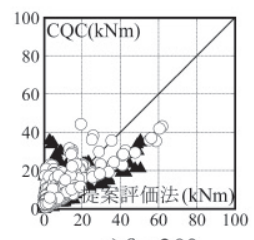

a) $\theta=30^{\circ}$

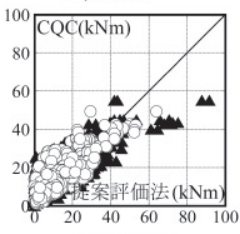

b) $\theta=60^{\circ}$

3)曲げモーメント

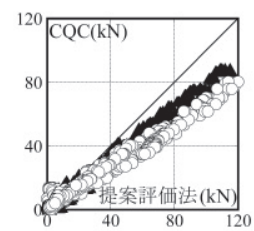

c) $\theta=90^{\circ}$

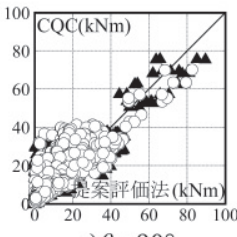

c) $\theta=90^{\circ}$

図 15 提案評価法の各変化量の精度(RS, RA モデル)

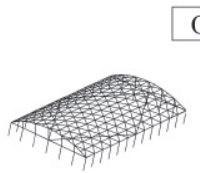

$100 \%, 1.60 \mathrm{~s}$ a1)FSf30-0.01

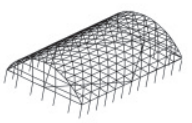

$99.98 \%, 1.21 \mathrm{~s}$ b1)FSf60-0.01

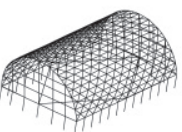

$99.96 \%, 1.14 \mathrm{~s}$ c1)FSf90-0.01

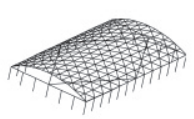

$100 \%, 1.53 \mathrm{~s}$ a1)FAf30-0.01

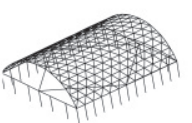

$99.95 \%, 1.12$ b1)FAf60-0.01

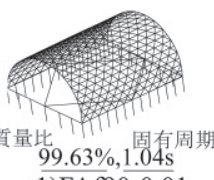

c1)FAf90-0.0

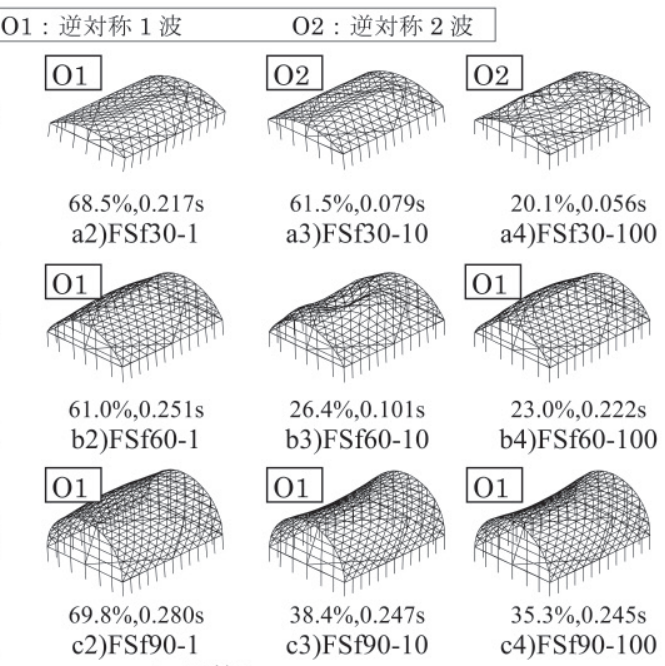

1) 円筒シェル

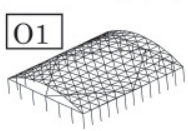

$53.9 \%, 0.224 \mathrm{~s}$ a2)FAf30-1

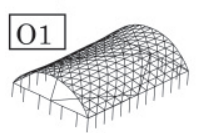

$58.7 \%, 0.271 \mathrm{~s}$ b2)FAf60-1

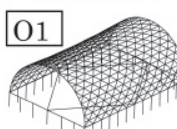

$72.5 \%, 0.394 \mathrm{~s}$ c2)FAf90-1

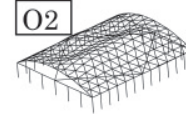

$57.4 \%, 0.082 \mathrm{~s}$ a3)FAf30-10

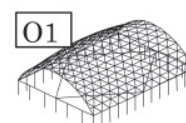

$34.8 \%, 0.247 \mathrm{~s}$ b3)FAf60-10

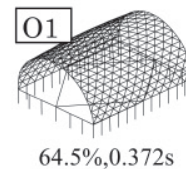

c3)FAf90-10

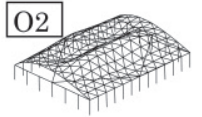

$20.7 \%, 0.074 \mathrm{~s}$ a4)FAf30-100

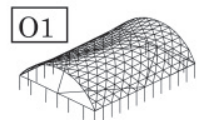

$32.7 \%, 0.245 \mathrm{~s}$ b4)FAf60-100

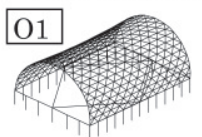

$63.6 \%, 0.37 \mathrm{~s}$ c4)FAf90-100
図 16 支持架構付きモデルの卓越固有モード 
3 章と同様の解析を行い, その地震応答特性を分析する。図 17 に $\theta=30,60,90^{\circ}$ における $\mathrm{CQC}$ 法による解析值と周期比 $R_{T}$ との関係を式 (8),(9)の值と併せて示寸。水平応答増幅率は式(8)により概敉表現で きているが，鉛直応答増幅率 $F_{V}$ は半開角が大きくなるにつれ， $R_{T}$ の増加に伴う $F_{V}$ の低下が大きくなり, より小さな $R_{T}$ で 0 に収斂す る。そのためライズの高い範囲では式(9)による評価は過大となる。 これらの傾向は同図に示していないその他の半開角においても確認 できる。また既論文 ${ }^{14}$ における高ライズドームにおいても類似した 特性を示す。そこで半開角の大きな範囲での鉛直増幅率 $F_{V}$ の傾向を 捕捉できるように式(8)中の第 2 式に半開角 $\theta$ を含む下式を用いる。

$$
F_{V}= \begin{cases}3 C_{V(\theta)} & \left(0<R_{T} \leq 5 / 16 \sqrt{2 \theta}\right) \\ \left(\sqrt{5 / \sqrt{2 \theta} R_{T}}-1\right) C_{V(\theta)} & \left(5 / 16 \sqrt{2 \theta}<R_{T} \leq 5 / \sqrt{2 \theta}\right) \\ 0 & \left(5 / \sqrt{2 \theta}<R_{T}\right)\end{cases}
$$

ただし, $\theta$ の単位は(rad)とする。

式(22)は $\theta=30^{\circ}=0.52 \mathrm{rad}$ のとき, $\sqrt{2 \theta} \fallingdotseq 1$ となり, 式(9)とほぼ一致 する。図 17 に式(22)で評価した鉛直応答増幅率を破線で示す。半開 角 $\theta$ を用いて補正したことで, 半開角の大きな範囲でもその傾向を 精度よく表現できていることがわかる。ただし，図 17 の 2)のa)に おいて, $R_{T}=1$ 付近で $\mathrm{CQC}$ 法による解析值が予測式を大上回ってい

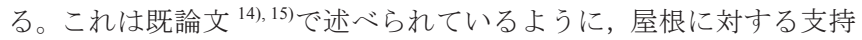
架構の質量比 $R_{M}$ が 1.2 を超える場合には, $R_{T}=0.8 \sim 1.2$ の範囲で屋根 部が共振を起こし，応答増幅率が増大寸るためである。

次に, 式(5) (9), (22)で評価した応答増幅率 $F_{H, V}$ を用いて, 式 (18) (21)により応答加速度分布を評価する。図 18 にCQC 法による 解析值と評価式による応答加速度分布との中央線 $\mathrm{AOA}^{\prime}$ 上の值の比 較を下部構造剛性，半開角ごとに示す。図 18 の 4)FSf30-1, FAf30-1 では $R_{T} \fallingdotseq 1.0$ となり屋根部が共振を起こすために応答増幅率が増大
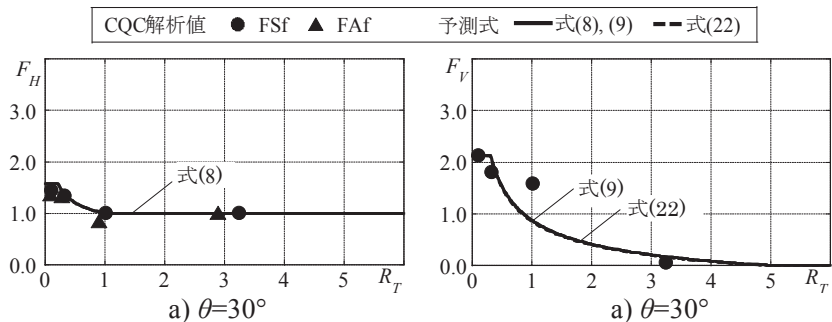

a) $\theta=30^{\circ}$

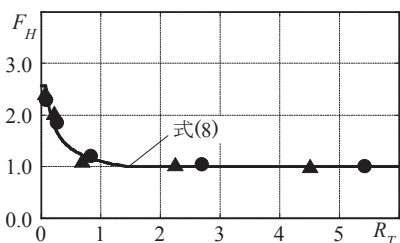

b) $\theta=60^{\circ}$

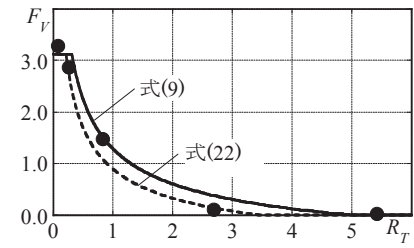

b) $\theta=60^{\circ}$

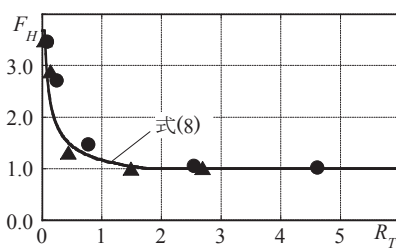

c) $\theta=90^{\circ}$

1)水平応答増幅率(FSf, FAf)

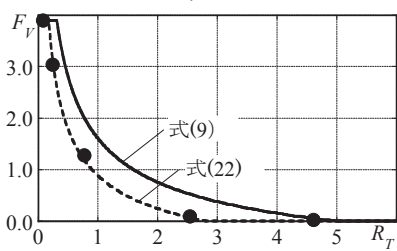

c) $\theta=90^{\circ}$
し，やや危険側の評価となる他は，半開角，下部構造剛性倍率によ らず概ね精度よく表現できていることがわかる。

図 19 に式(5) (9), (18) (22)で求まる屋根各部の応答加速度に屋根 単位荷重を乗じたものを静的地震荷重として使用した際の水平・鉛 直変位, 軸力, 曲げモーメントにおける提案評価法の精度を示す。 屋根モデルと同様に，曲げモーメントについての精度は必ずしも高 くないが，水平・鉛直変位および軸力については半開角 $90^{\circ}$ 至る まで良好な精度を示す。

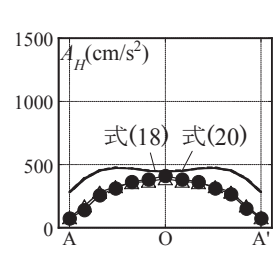

a)水平方向 1)FSf30-100, FAf30-100

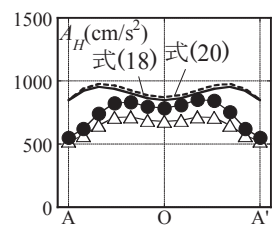

a)水平方向

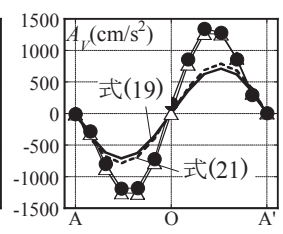
4)FSf30-1, FAf30-1

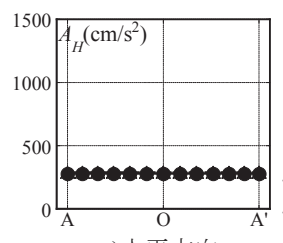

a)水平方向

7)FSf30-0.01, FAf30-0.01
CQC解析值 - - FSf $\triangle$ FAf 予測式 —FSf:式(18), (19) - FAf:式(20), (21) b)鉛直方向

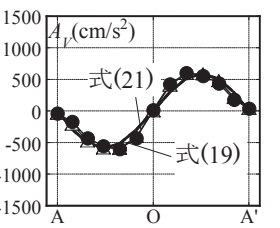

b)鉛直方向

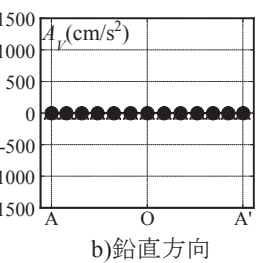

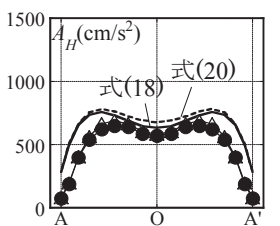

a)水平方向

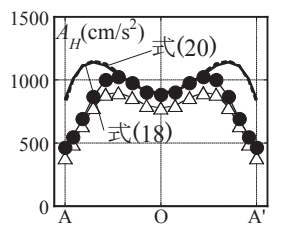

a)水平方向

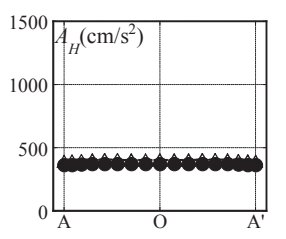

a)水平方向 2)FSf60-100, FAf60-100

5)FSf60-1, FAf60-1

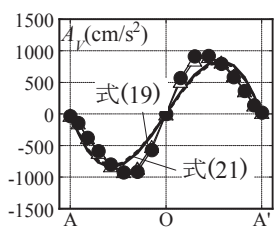

b)鉛直方向

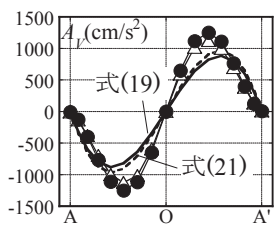

b)鉛直方向

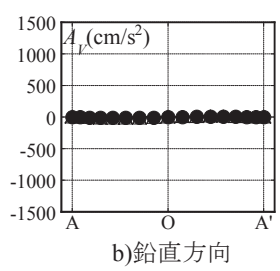

b)鉛直方向

8)FSf60-0.01, FAf60-0.01

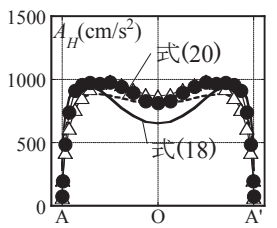

a)水平方向 3)FSf90-100, FAf90-100

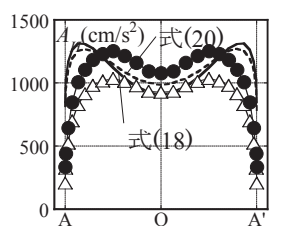

a)水平方向 6)FSf90-1, FAf90-1

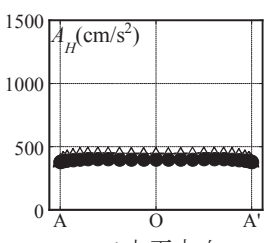

a)水平方向

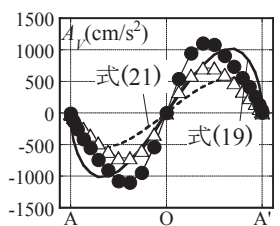

b)鉛直方向

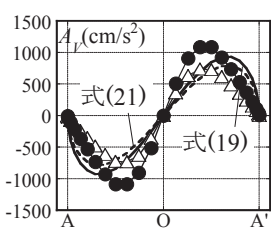

b)鉛直方向

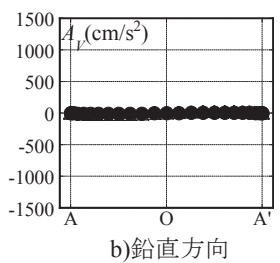

)鉛直方向
図 18 支持架構付きモデルにおける中央線上応答加速度 
次に非剛床モデルにおける提案評価法の精度について分析する。 図 20 に非剛床モデルと剛床モデルの応答加速度および式(5) (9), (18) (22)を適用した際の提案評価法の精度の比較を示す。低ライズ での非剛床モデル(FS30-1)は剛床モデル(FSf30-1)よりも外周部の水 平応答加速度がやや増幅する傾向がある。ただし, 高ライズになる につれて非剛床モデル(FS60,90-1, FA60,90-1)では剛床モデル (FSf60,90-1, FAf60,90-1) とほぼ等しい応答加速度となる。この傾向は 同図で示していないその他のモデルにおいても同様の傾向が見られ
る。これは高ライズの屋根では図 2 に見るように屋根全体のスウェ イモードが主体となり，支持架構平面のゆがみを伴う振動モードの 有効質量比が低下寸るためと考えられる。しかし，低ライズにおい ても非剛床モデルと剛床モデルの応答変化量の差は小さく, 同図よ り非剛床モデルも剛床モデルと同様に提案評価法によって精度よく 評価できていることがわかる。従って，今回の網目形状の円筒シェ ル屋根では屋根支持面のゆがみによる影響は限定的であると言える。

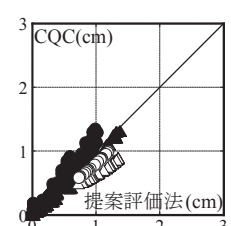

a)FSf,FAf30-1

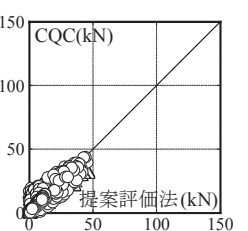

a)FSf,FAf30-1

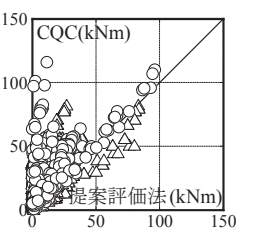

a)FSf,FAf30-1

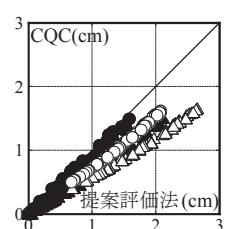

b)FSf,FAf60-1

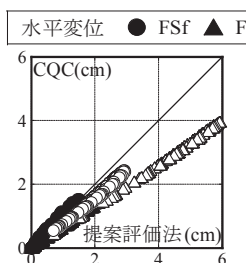

c)FSf,FAf90-1

1) 水平・鈶直変位

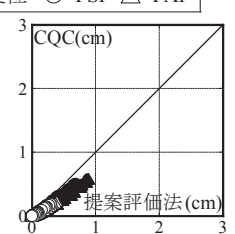

d)FSf,FAf30-100

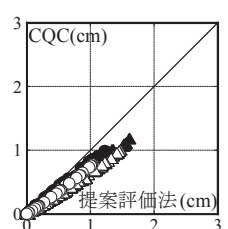

e)FSf,FAf60-100

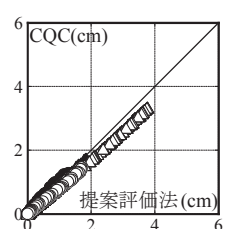

f)FSf,FAf90-100

軸力, 曲げモーメント ○ FSf $\triangle \mathrm{FAf}$

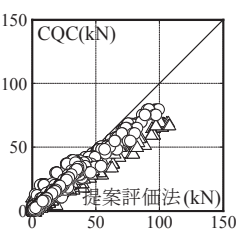

b)FSf,FAf60-1

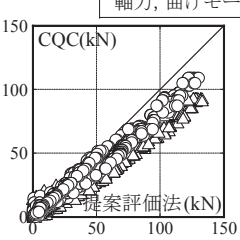

c)FSf,FAf90-1

2) 軸力

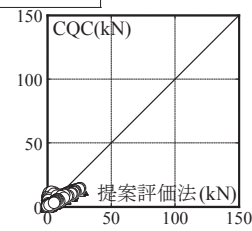

d)FSf,FAf30-100

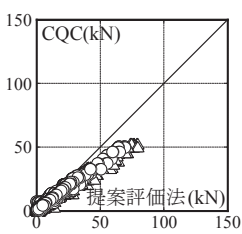

e)FSf,FAf60-100

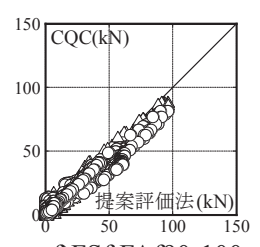

f)FSf,FAf90-100
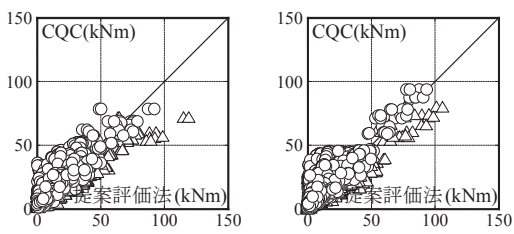

c)FSf,FAf90-1

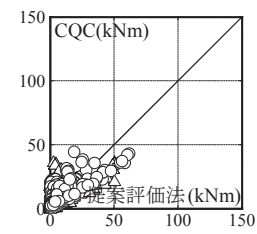

d)FSf,FAf30-100

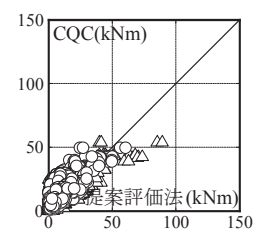

e)FSf,FAf60-100

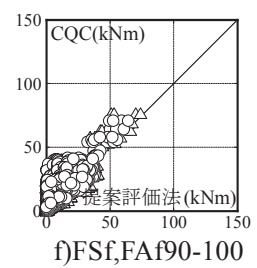

図 19 支持架構付きモデルにおける提案評価法の精度(屋根部変化量)

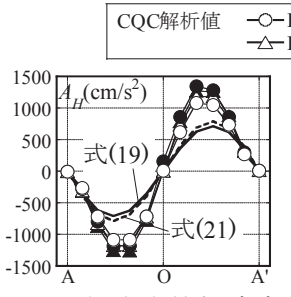

b)鉛直応答加速度

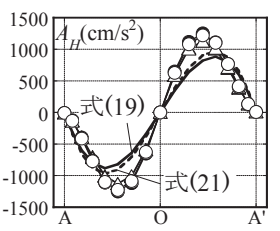

b)鉛直応答加速度

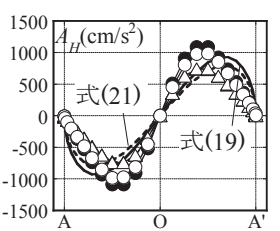

b)鉛直応答加速度

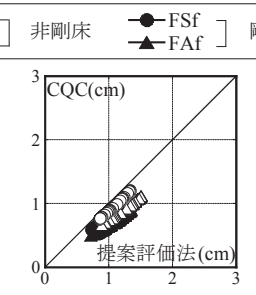

c)水平変位

1) FS(f)30-1, FA(f)30-1

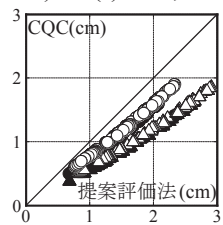

c)水平変位

2) $\mathrm{FS}(\mathrm{f}) 60-1, \mathrm{FA}(\mathrm{f}) 60-1$

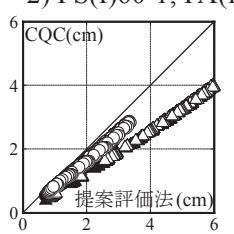

c)水平変位

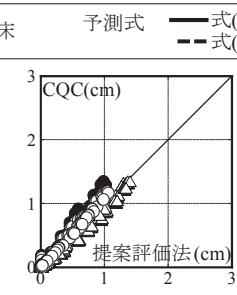

d)鉛直変位

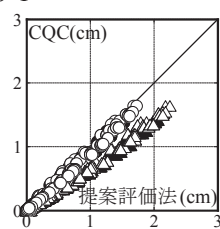

d)鉛直変位

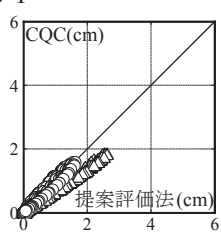

d)鉛直変位

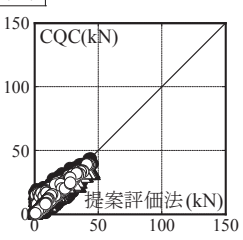

e)軸力

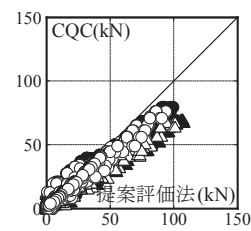

e)軸力

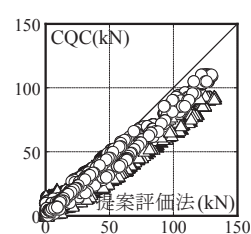

e)軸力

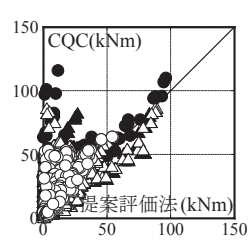

f)曲げモーメント

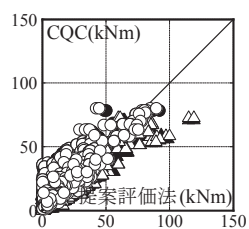

f)曲げモーメント

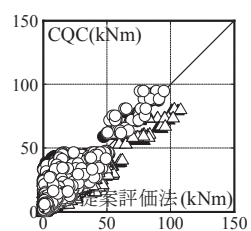

f)曲げモーメント

図 20 支持架構付き非剛床モデルにおける提案評価法の精度 


\section{5. 結}

半開角 $30^{\circ} \sim 90^{\circ}$ の高ライズの円筒シェルおよび円筒アーチについ て, まず屋根モデルを用いてその応答増幅率および応答加速度分布 を分析し, 既往の応答評価法の精度を確認した。次にこれを応用し, 支持架構を有し周期比の異なるモデルに対する応答評価法を提案し, その精度の確認を行った。以下に得られた知見を示す。

1) 半開角 $90^{\circ}$ のイズの大きな円筒アーチに対して 2 質点アーチ より導出される近似式を用いることで精度よく応答増幅率を評 価できる。また半開角 $90^{\circ}$ のイズの大きな円筒シェルに対して は 2 質点アーチより導出される近似式に, 桁行/スパン比の影響 を考慮し既往式を高ライズ領域で補正することにより，精度よ く応答増幅率を評価できる。

2）高ライズドームに関する既論文 ${ }^{15)}$ と同様の手法を用いて, 屋根 部節点を極座標表示し，既往の水平・鉛直応答加速度を分解・ 再合成することでライズの増加に伴う屋根各部の応答加速度分 布の変化を表現することができる。

3）支持架構付き円筒ラチスシェルの周期比の地震応答への影響は 高ライズドームに関する既論文 ${ }^{15)}$ と同様の手法を用いて, 既往 の予測式に半開角の影響を考慮し, 高ライズ領域の補正を行う ことで精度良く評価できる。提案した補正式は既往の研究の適 用範囲である半開角 $20^{\circ} \sim 40^{\circ}$ を超え, $90^{\circ}$ まて適用可能となる。

4) 屋根支持面のゆがみにおける影響は，今回採用した網目形状の ラチスシェルでは限定的であり，高ライズになる程その影響は 小さい。

\section{参考文献}

1) 竹内明子, 山田聖志, 多田敬幸: 単層円筒ラチスシェル屋根を有する鋼構 造物の地震応答性状, 鋼構造論文集, 第 6 巻第 23 号, pp.91-98, 1999.9

2) 安田勝範, 山田聖志 : RS 座屈設計された単層屋根型円筒ラチスシェルの地 震応答特性, 日本建築学会大会学術講演梗概集(東北), B-1 分冊, pp.923-924, 2000.9
3) 山田聖志, 廣澤孝明 : 単層屋根型円筒ラチス構造の地震時応答特性の分析, 日本建築学会大会学術講演梗概集(関東), B-1 分冊, pp.807-808, 2001.9

4) 山田聖志, 松本幸大, 加藤史郎 : 屋根型単層円筒ラチスの地震動による応 答性状と静的地震荷重に関する考察, 鋼構造論文集, 第 11 巻第 41 号, pp. $33-46,2004.3$

5) 山田大彦: 空間構造の地震応答に及ぼす下部構造の影響に関する初歩的考 察, 第 10 回シェル・空間構造セミナー資料，日本建築学会，2001.11

6) 鄭讃愚, 山田大彦:アーチの地震時加速度応答分布特性 一変位, 加速度, 縁応力または反力を判定基準とした分布特性一, 日本建築学会大会学術講 演梗概集(東北), B-1 分冊, pp.859-860, 2000.9

7) 加藤史郎, 石川浩一郎, 高シン：上下振動を考慮した大スパンアーチ構造 の等価静的地震力, 日本建築学会大会学術講演梗概集(関東), B-2 分冊, pp.479-480, 2001.9

8) 篠原陽介, 鄭讃愚, 山田大彦: アーチの地震時加速度応答分布特性(その 2), (その 3), 日本建築学会大会学術講演梗概集(関東), B-1 分冊, pp.765-768, 2001.9

9) 末岡利之, 元結正次郎, 伍賀信輔, 日比野智也 : 水平地震動を受けるア一 チ架構の幾何学的非線形性を考慮した静的地震力の推定法(その 1), (その 2), (その 3), 日本建築学会大会学術講演梗概集(北海道), B-1 分冊, pp.791-792, 2004.8

10)加藤史郎, 向山洋一, 植木隆司: 高ライズの単層ラチスドームの地震応答 性状，日本建築学会構造系論文報告集 No.442,pp.101-109, 1992.12

11)加藤史郎, 向山洋一: 高ライズラチスドームの地震層せん断力係数に関す る研究, 日本建築学会構造系論文集 No.466, pp.87-95, 1995.1

12)竹内徹, 小河利行 : 空間構造の応答性状と制振・免震技術の応用, 2005 年 度日本建築学会大会(近畿)構造部門(シェル・空間構造)パネルディスカッシ ヨン資料 体育館・公共ホールの地震被害と耐震改修, pp28-39, 2005.9

13)小河利行, 中川美香, 熊谷知彦: 応答スペクトル解析法を用いた単層ラス ドームの地震応答解析, 構造工学論文集, Vol.49B, pp.291-296, 2003.3

14)竹内徹, 小河利行, 山形智香, 熊谷知彦: 支持架構付き屋根型円筒シェル の地震応答評価, 日本建築学会構造系論文集, 第 619 号, pp57-64, 2005.10

15)竹内徹，熊谷知彦，岡山俊介，小河利行 : ライズの高い支持架構付きラチ スドームの地震応答評価, 日本建築学会構造系論文集, 第 629 号, pp1119-1126, 2008.7

16)建設省建築研究所：建築研究資料 No.83 設計用入力地震動作成手法, 1994.11

17)笠井和彦，伊藤浩資，渡辺厚 : 等価線形化法による一質点系弾性構造の最 大応答予測, 日本建築学会構造系論文集, No.571, pp.53-62, 2003.9

（2011年 3 月 6 日原稿受理，2011年 4 月 26 日採用決定） 